\title{
Welfare Frontiers? Resource Practices in the Nordic Arctic Anthropocene
}

\author{
Frida Hastrup and Marianne Elisabeth Lien
}

\begin{abstract}
This article outlines the thematic section's main anthropological interventions and introduces the inherently ambiguous notion of welfare frontiers, implying allegedly benign practices of resource development. Through ethnographic analyses from Iceland, Norway, and Greenland, it shows that Nordic Arctic landscapes become resourceful through careful crafting, entangled with practices and ideals of nation-building, egalitarianism, sustainability, good governance, and a concern for liveability for legitimate citizens. Further, the authors suggest that seeing natural resource development as linked to specific welfare state projects, with attention to the sometimes colonizing aspects of such practices, specifies and captures the current era, bringing the Anthropocene back home.
\end{abstract}

\section{KEYWORDS}

commons, colonial practices, egalitarianism, landscape, liveability, welfare state, Nordic Arctic

What do natural resource frontiers look like when configured within the highly regulated systems of wealth redistribution, welfare provisions, and environmental governance that characterize the Nordic states? This is the overarching question that we probe in this thematic section. The Nordic Arctic region is a site of significant resource extraction and production, but resource practices in the region pose particular questions: how do national commitments to notions of commons, egalitarianism, and welfare state policies play out in the making, managing, and developing of natural resources in the Nordic Arctic? How are global trade, histories of colonial activity, experiences of scarcity, scientific innovation, and national ambition implicated in generating northern resource landscapes?

The articles in this thematic section address these questions through five fine-grained ethnographic cases from Greenland, Iceland, and Norway. What is clear across these studies is that the resourcefulness of these places is by no means a naturally inherent landscape feature, although it may be portrayed as such. Rather, the particular landscapes in this northern part of Europe appear resourceful through 
careful crafting, entangled in broader schemes of nation-building, economic sustainability, transparent decision-making, publicly funded science, and state formation. A premise for the articles that follow is thus that resourcefulness is a negotiated quality. These negotiations are what we specify regionally by thinking through resource projects in the Nordic Arctic.

Exploring how Nordic Arctic landscapes are crafted as resourceful (or not) with a view to political concerns for the common good is a matter of investigating how these landscapes are made liveable in specific ways - whether by locals, corporate actors, state representatives, scientists, or other actors (usually in some kind of collaboration). Generally, it is seen (and to some extent legally codified) as the duty of a Nordic welfare state to ensure that citizens can, in fact, live anywhere in the country and still have their basic needs met in terms of infrastructure, health care, schooling, child care, and so on. Even in a small country like Denmark, current debates address the need to support the country's peripheral regions (as seen from Copenhagen) that experience depopulation, decreased primary production and loss of jobs (cf. Høst 2016). In 2015, the Danish government initiated a plan to transfer some 8,000 public jobs to areas outside of Copenhagen with reference to the country needing to be 'better balanced'; growth and development should benefit the country as a whole and not be concentrated in the capital (Regeringen 2018). Similar measures are regularly taking place in Norway and Sweden. In Greenland, too, the villages need extensive financial support to stay alive, as huge distances between populated areas make it costly to support the necessary infrastructures (Flora 2019: 18; K. Hastrup 2015). One response to this was an extensive centralization policy in the 1960s, 'to once and for all stamp out the inequalities in Greenland by closing down many of the small villages and relocating entire populations to other larger villages and cities' (Flora 2019: 18). Centralizing policies were also implemented in Sweden and Norway. As these brief examples show, the motivation for action is equality - even if this has not been the result.

The aim here is to explore such appeals to equality and liveability through (often state-sanctioned) natural resource development projects in the Nordic Arctic region - whether undertaken to make people stay in place through offering employment, by assessing what is even profitable, or by generating value to be distributed in society. At issue in the cases we present, is how a kind of 'benign resource development' emerges in the Nordic Arctic and how a 'welfarist' and egalitarian morality is implicit in such projects. 
The articles that follow offer ethnographies of what we refer to as welfare frontiers, a concept that is deliberately ambiguous and captures a dual aim. On the one hand, it indicates that configurations of resourcefulness involve practices of exploiting, controlling, and even colonizing land seen as somehow peripheral, uninhabited, up for grabs, exploitable from elsewhere, and in need of pioneering development and resource transfer. Hence the notion of 'frontier'. On the other hand, 'welfare frontiers' point to the efforts to advance and realize particular democratic visions of good living conditions for all legitimate citizen-subjects, even in regions seen by state authorities as marginal in one way or another. The particular kinds of industriousness that make and have made Nordic Arctic landscapes resourceful are thus effects of specific ideas about proper governance, common liveability, and shared responsibility for decent livelihoods (cf. Brichet and Hastrup 2018, Lien 2018). The articles of this thematic section show that a specific mode of making resources, based on a combination of exploitative policies, efforts at improvement, and principles of re-distribution, is inherent in Nordic welfare state-making. This, we argue, constitutes a specific formation of resource frontiers, and responds to an overall concern with the viability of seemingly peripheral areas of the nations in question.

\section{The Making of Natural Resources}

Theoretically, we want to enhance recent anthropological understandings of resource-making as the outcome of coordinated activities that together enact certain substances as assets (e.g. Bubandt and Tsing 2018; F. Hastrup 2014; 2018; Lien 2015, 2017; Tsing 2005). As anthropologists Tanya Richardson and Gisa Weszkalnys note, resources become historically and ontologically, resulting from 'processes and practices of abstraction, homogenisation and standardisation aimed at inscribing the boundaries between nature and culture' (2014: 22). Even though we refer to welfare states in the Nordic region of Europe, the research we engage with includes a broad range of anthropological studies addressing questions such as how environments are performed, how resources emerge, and how entanglements between human and other-than-human entities play out. In so far as we discuss state formation, legal frameworks and formal policies, we see these as part of our empirical material, rather than explanatory frames or political science concepts. 
In the twenty-first century, discussions around human disturbance of the globe's ecosystems have deeply affected anthropology - a field committed to the study of people and their worlds. Geologists have suggested that our current era is the 'Anthropocene', that is, marked so heavily by human activities so as to label the 'anthropos' a geological force (Crutzen and Stoermer 2000). Whether or not one fully ascribes to this label, the concept has already spurred all kinds of discussions within anthropology (Swanson et al. 2015). The artist and environmental anthropologist Elaine Gan phrases the invitation posed by the notion like this:

The word tells a big story: living arrangements that took millions of years to put into place are being undone in the blink of an eye. The hubris of conquerors and corporations makes it uncertain what we can bequeath to our next generations, human and not human. The enormity of our dilemma leaves scientists, writers, artists, and scholars in shock. How can we best use our research to stem the tide of ruination? (Gan et al. 2017: G1)

In this thematic section, our reply to this urgent question is a very anthropological one, that is, to work through specific ethnographies and to productively ignore how 'cases' may be seen to qualify as 'big' or 'small'. We thus respond to current global challenges by situating resource projects in specific contexts where they play out in ambiguous ways, as captured in the deliberately oxymoronic notion of welfare frontiers. The ambition is thus to address particular anthropogenic landscapes in a Nordic Arctic setting and to see them as completely entangled in so-called first world politics. Through this approach to Nordic Arctic resource practices, we are attentive to the deep-seated commitment to welfare provisions that pertains to the welfare states in the north, and explore how this unfolds as subtle resource configurations, for better or for worse. The articles that follow detail how - in the process of welfare state provisioning - geothermic heat and water, an apple, the thin topsoil of barely arable land, a fox skin, a rare earth mineral, or a gemstone come to appear as vital yet ambiguous resources.

Our exploration of welfare frontiers is an invitation to consider the Nordic Arctic region not only through panoramic images of geopolitical battles, mineral potentials, and melting ice, but also as a rich site for anthropological inquiry about the nature of a part of Europe in this day and age. What is the nature, we ask, of welfare frontiers? Locating natural resource questions squarely in our midst, we aim to muddle the picture of capitalist resource extraction or procurement 
as necessarily motivated by economic gain, maybe aided by violent and colonial practices, as often claimed (e.g. Tsing 2015; Grove 2019; Livingston 2019; Cons and Eilenberg 2019). Rather than address neoliberal resource extraction motivated by dreams of conquest and expansion, our analyses of utilization do not easily lend themselves to binaries of exploitation vs. resistance or colonialism vs. indigeneity, although such issues may be subtly at play. A central argument is that we need to explore what we could refer to as 'compliant modes' of resource extraction as a vital part of both North European culture and anthropogenic ecologies. Our aim is not to relativize human disturbances, but to analyse them through regional and historical specificity. This implies that we need to de-centre an understanding of colonialism as 'settler colonialism', a perspective that tends to assume conquest as a watershed moment that works from clear-cut distinctions between before and after, indigenous and non-indigenous, and native and invasive species (cf. Crosby 2015). In such a perspective, settler colonialism commits environmental injustice as it 'works strategically to undermine Indigenous peoples' social resilience as self-determining collectives' (Whyte 2018:125). While this may often be the case in settler colonial settings, we want to draw attention to regions where singling out indigenous peoples is not so straightforward, where the 'self-determining collective' thus takes on different forms, and where such collectives can even be complicit in practices that have a colonial component. Hence, the articles that follow intentionally 'trouble' existing notions of ecologic imperialism and environmental injustice as seen through the settler colonialism lens. Instead, we offer ethnographic cases that imply shifting and notoriously unstable distinctions between the colonizer and the colonized.

In the following sections of this introduction, we draw out some of the cross-cutting themes that the articles in this thematic section address. This will show the connections between them as well as their respective emphases.

\section{A Liveable North between Scarcity and Abundance}

The Nordic Arctic landscapes are grounds for unstable configurations of both scarcity and abundance. Historically, images of a barren, cold, and seemingly empty Arctic have depicted the region as the northern frontier of human subsistence; a masculine playground for courageous explorers (Bravo and Sörlin 2002, K. Hastrup 2010; K. Hastrup, 
this volume). The north has also been portrayed as a vast landscape of untapped natural plenty somehow up for grabs: fish, minerals, petroleum, metals, and energy are but some of the potential resources seen as ripe for development by shifting constellations of people, states, and corporations - interchangeably interested in economic growth and green shifts (Kristoffersen and Langhelle 2017). These notions of an untamed frontier and its resource potential are increasingly layered with another image: that of a pristine yet threatened nature. As a scene for melting ice, temperature rise, and as home to life forms, human as well as non-human, perceived as close to extinction, the Nordic Arctic has become a frontline for scientific exploration in the Anthropocene and exemplifies the dire consequences of human disturbance (see e.g. Ween 2015). The combination of forbidding scarcity, promising potential, and environmental showcase engenders intriguing Nordic Arctic resource futures, and mobilizes configurations of profitable enterprise, as well as state-promoted imageries of what constitutes a good life. The interplay of capitalist enterprise, state-projects of resource extraction and the subtle, sometimes colonial, governance of relations between people and land constitutes the thrust of our ethnographic inquiry.

A central question is how Nordic Arctic frontier landscapes are composed as 'resourceful' in the first place. From which perspectives and according to which yardsticks are these places seen to hold valuable resources? What kinds of interventions are needed to stabilize some places as home to particular resources, and how are these made manageable through policies conceived at a distance, such as in the capitals of Copenhagen, Nuuk, Reykjavik, or Oslo? What scales of comparison are at play to render certain places empty and 'lacking', and what practices and promises transform them to viable regions of plenty? If, as Richardson and Weszkalnys have remarked, 'Natural resources are ubiquitous and energetic substances that play an active part in the making of worlds' (2014:7), what part may that be? And how do the parts played in the selected ethnographic cases, in turn, qualify what we think of as welfare frontiers?

One characteristic feature of the Nordic Arctic resource landscapes we explore here is that nature was never cheap (cf. Moore 2014). There never was an unlimited and allegedly expendable and replaceable supply of workers to be employed by states or others in extractive projects; nor are lands readily arable and accessible. Indeed, many of the Nordic regions that are perceived as resourceful in terms of natural assets are in fact very sparsely populated and require intensive - and 
expensive - efforts to ensure the yield of whatever resource in question. This is not to accept the colonial trope of the colonies and peripheries being uninhabited territory there for taking, but rather to stress that part of the ambition to make the welfare resource frontiers liveable is to actively counter, or at least manage, depopulation - whether by bricolage practices of generating income or by way of formal settlement policy. Indeed, as we shall see, it takes much work on the part of state authorities to keep some of the explored regions inhabited. These efforts, again, hinge on the recognition of particular landscape features as resources at the expense of others - an assessment sometimes based on a systematic ignorance of resource formations that do not fit a state's view of what counts as assets and, accordingly, what counts as inhabited land (see for example Anderson and Nuttall 2004; Lien, this volume). Thus, many different practices that have made northern landscapes viable and which have been passed down locally for generations are often ignored, implicitly or explicitly, as a first step towards resource extraction is often to conjure an image of an empty land ripe for state intervention. As intimated above, the perceived emptiness is not just the well-known colonial practice of instrumentalizing and appropriating conquered land elsewhere. Rather, it is the centralized attempt at making governance, livelihoods, resource projects, and populations map precisely onto one another - in ways that make them not only legible (cf. Scott 1999) but also resourceful, from the perspective of the nation state.

\section{Nordic Arctic Resource Projects - an Overview of the Contributions}

In Kirsten Hastrup's article we learn of the Thule region in Northwest Greenland as being somehow suspended in time. It is as if the community there does not really know whether to bet on an incipient mining industry, new marine resources resulting from the warming of the area's waters, or - alternatively - to make a living from embodying the threatened life form of hunter-gatherers and make their skills available, by assisting scientists that seek to document global climate change. If none of these options actually materialize or can be sustained, people will have to move south - to other parts of Greenland or to Denmark, of which Greenlanders are legal citizens. Current national Greenlandic politics addressing how and whether to keep supporting the country's northern villages is an acute example 
of the issue of populating landscapes, just as ideas of mutual entitlements between Denmark and Greenland - and the geopolitical location between Russia and the US - make the Thule area anything but peripheral. As the article shows, sustaining the Thule region as liveable requires all manners of tinkering and creative practices that take us well beyond natural scientific mapping of resources. Plenty of hard decisions have to be made - even in places that can be cast as naturally plentiful and as an untouched resource of bare human life. Even here, to see resource use merely as a matter of 'tapping' what is already there misses the mark.

As James Maguire shows, the presence of geothermal water in the Icelandic underground was the precondition for the founding and growth of the city of Reykjavík and, indeed, for making the island as a whole inhabitable since the Middle Ages. Water warmed by volcanic activity made the country human terrain. The trouble today, however, is that recent practices to expand the utilization of geothermal energy to supply an aluminium industry with cheap power appear to induce man-made earthquakes. Unsurprisingly, villagers living nearby an important geothermal plant are concerned, as they now literally find themselves on rather unstable ground. The article describes the various dilemmas about resource exploitation and control seeping out from the Icelandic underground, and shows how they play a vital part in deciding where it is possible to live. Should a few villagers be able to stand in the way of the city of Reykjavík or prevent the country from profiting from geothermal resources?

Such tensions between perceived centres and peripheries are also apparent in Marianne Elisabeth Lien's and Frida Hastrup's articles, showing how at different historical junctures the Norwegian state crafted active policies to populate the seemingly remote regions and optimally use what the landscape is seen to offer. Implementation of and support for agricultural and horticultural production have served as means to this end, even if it implied pushing the cultivated frontier further north, conceivably beyond what was and is ecologically possible (F. Hastrup, this volume). Additionally, the Norwegian nation state's sparsely populated regions bordering Russia and Finland have invariably been seen as a risk to territorial sovereignty (Lien, this volume). From the perspective of the twentieth century state authorities, these landscapes were lacking the proper kind of people, and policies were put in place to encourage settlement by a Norwegian-speaking population whose relations to land could mimic agricultural practices further 
south. This implied marginalisation, if not replacement, of traditional Sámi patterns of seasonal migration and of multiple landscape engagements, already practised by people living there. Lien shows how geopolitical concerns and population politics merge with resource practices in shaping indigeneity and 'Norwegian-ness' in the Arctic North.

Arability in these Nordic Arctic terrains, however, was and is costly and hard to come by. Although rooted in far more fertile land than the Finnmark of Lien's analysis, apple production in western Norway in the twenty-first century is completely dependent on import barriers and taxation schemes. Frida Hastrup describes how the Norwegian fruit landscape is cast as a naturally abundant orchard and simultaneously as a site in need of intense state intervention. Resource imaginaries, in other words, are not that easily realized, and sometimes they are just that: imaginaries. Similarly, even if mineral resource exploitation in Greenland is seen by some as a means to achieve economic independence (see Nuttall 2012), sustaining a viable economy without the support of the country's former colonizer Denmark remains a vision with no immediate prospects of being realized (e.g. Rosing et al. 2014). In spite of the official government strategy to prioritize the mineral industry in Greenland, the country now has next to no mining activity (cf. Brichet 2018). The value of the Greenlandic underground, to be sure, has long been a complicated matter.

As Nathalia Brichet shows in her contribution, surveys of the Greenlandic geology have long been the province of experts and advisers from elsewhere, notably Denmark, and mapping and marketing the country's mineral resources are not neutral activities. Ranging from the Danish-Norwegian king, through jewellers appointed by the Royal Danish court to the geological survey of Denmark and Greenland, outsiders have taken to the Greenlandic mountains to assess the deposits and values nested in the rock formations. In the case of gemstones, such mappings, as Brichet's article shows, sometimes primarily conclude what is not available in the country's underground, rather than assessing the Greenlandic geology as a case in itself. Reports, primarily from the 1960s and 1970s, thus tell of limited potential for commercial gain from Greenlandic gems and tend to relegate the finds to the realm of souvenirs and native handicraft, thereby implicitly questioning the economic viability of the country. The history of colonial governance, then, expresses itself both in an effort to help develop a local industry to the benefit of all Greenlanders and in the privilege to assess whether such industry might be sustainable at 
all. The point is that such mapping exercises often portray the colonized region as lacking, effectively reproducing the colonial yardstick, simultaneously charting both what is missing and the alleged remedy, without heeding subtle practices that make and have made the places liveable to locals for centuries (see also Lien, this volume).

In all of these cases, then, resource practices appear closely intertwined with efforts to make a place inhabitable and resourceful by whatever means. These involve more-than-local concerns and morethan-local practices of governance, in which conflicting ideas about growth and the realization of resource potentials rub up against multiple visions of what constitutes a good and viable life in the region.

\section{Scalable Northern Commons?}

A key issue in the cases explored in this thematic section is the question of scale. Measuring and up-scaling the different resource projects in the Nordic Arctic have proven difficult, as several articles show. In Northwest Greenland, no metric really applies since the landscapes are extremely volatile, as game, ice, water, and people move around in increasingly unpredictable ways. Further south in Greenland, the local gemstones are seen as relevant and valuable only on a local scale, and not as 'international items' - unless a foreign investor can enter and fund a high-tech mine. The model of Norwegian agriculture conceptualized from the fertile southern region of Norway was never easily implemented further north. In the north of the country, a shift to farming was meant to cultivate both the land and the indigenous Sámi population, while at the same time securing Norwegian settlement near the border towards Russia. Further, in the apple region in the west-Norwegian fjords, small-scale production marks the very identity of the enterprise, even if state incentives to upscale through centralization and expansions are in place. A tale of national self-sufficiency forms part of the picture: Norwegian apple producers supplying Norwegian consumers with Norwegian fruit is a project that guards the national borders rather than expands beyond them.

Similarly, as underground forces belonging in Icelandic deep time are suddenly brought to the surface, a new potential rift in Iceland has emerged, namely whether to accept the risk faced by the few people living adjacent to the geothermal facility in order to cater to the many in the capital, or to 'un-develop' the geothermal resources 
because of the threat to a small minority. Scaling up, in this case beyond the heating of the city of Reykjavík to supply aluminium smelters with cheap energy, is a complicated matter. In the Icelandic case described here, one might say that the very notion of the common good is complicated, because of the dilemma in deciding whether geothermal energy should benefit the many at the potential risk of the few or be left underground so that the vicinity of the heat facility remains liveable.

Thus, if in many cases expansion is the prime motor of global modernity and scalability a hallmark of success (cf. Tsing 2005), the resource projects explored here complicate such claims. For one thing, by probing whether and how to sacrifice the need of a few to benefit the many, and for another by showing how local consolidation and self-sufficiency sometimes seem more of an impetus than up-scaling. On both accounts, the articles 'melt' the otherwise often insoluble link between resource projects and growth (see Hylland Eriksen and Schober 2018).

Central to each of the resource projects described in the articles that follow are efforts to secure a collective safety-net, a kind of liveability for the future that involves an apparatus for redistribution, even if this is knitted at the expense of local resource practices and environmental integrity. At stake is a certain notion of sustainable welfare at national or regional levels. The issue of scaling, then, is also temporal in that resource projects often have an implicit view to the future. The petroleum policy of the Norwegian state is an example of a mechanism that serves this aim, as it secures that surplus revenues from petroleum extraction will benefit future citizens through instruments such as the Norwegian Oil Fund, formally the Government Pension Fund Global (Norges Bank 2020). The stated aim of the oil fund is to ensure 'long-term management of revenue from Norway's oil and gas resources in the North Sea so that this wealth benefits both current and future generations' (Norges Bank 2020). Even though this is one of the largest sovereign wealth funds in the world, (holding about 10 billion Norwegian kroner in 2019 or about 2 million kroner per Norwegian citizen), the ideal of sharing state-controlled resource revenue is common across the Nordic region. The basic idea that socalled 'natural' resources are a common good and that liveability is a permanent right of all legal citizens calls upon the Nordic states to display a certain responsibility for stocking and managing the resources with a view to future livelihoods. 


\section{Nordic Colonialisms, Indigeneity, and Citizenship}

As noted, many anthropological analyses of colonialism derive from so-called settler contexts, that is, continents that were colonized, invaded, or inhabited as a result of long-distance migration or even conquest driven by blatant resource exploitation (cf. Australia, South America, North America, South Africa). Most settler nations point to a particular moment that stands for the first encounter; hence, in these places, there is a before and after colonialism, and there are clearly distinguishable populations, even if these mix over time. The picture is different in the Nordic Arctic. The region has been populated from many directions and through many waves of migration. Different people have settled at different times, sometimes side by side, and it is often difficult to ascertain both the ethnic identity of the earliest settlers and their exact place of origin. For instance, archaeologists have documented that Sámi peoples have been found across much of northern Scandinavia, and historical records have established beyond doubt that state and racist policies of discrimination and national assimilations have been practised in all the Scandinavian countries whose national borders encircle Saami lands (Naum and Nordin 2013; Keskinen et al. 2016). However, for all the forced assimilation and racism historically endured by some people in the north, to be indigenous is also to be a legal citizen of well-functioning states. As mentioned, this is also the case for Greenland, where people are legal citizens of the Kingdom of Denmark. It has been suggested that this legal entitlement causes 'colonial complicity', a specific trait of Nordic colonialism characterized by acceptance of colonial hegemonic discourse in order to become part of the centre (Vuorela 2016).

Part of the background for the Nordic ambition to redistribute common goods is a sense of homogeneity in terms of the people living in the region, making everyone equally entitled to a part of the shared resources. The anthropology of Scandinavia has thus evolved around issues of sameness, equality, and egalitarianism (Gullestad 1992, Bruun et al. 2011). We suggest that this may cast resource projects in the Nordic Arctic region as more harmonious than they often are. Hence, in the Nordic Arctic, colonialism, oppression of indigenous rights, and resource extraction do not map onto each other in any straightforward way. The picture is different from the one we might find in the American Arctic, for instance, where indigenous peoples are often organized in opposition to the state, fighting for recognition in their own right, not least when it comes to resource 
development projects and anthropogenic climate change. Resource extractions have transformed the land in the Nordic Arctic, but have also been instrumental in nation-building and the establishment of redistributive nation states. This situates indigenous inhabitants as both victims and recipients of the ensuing wealth.

In light of these blurred subject-object relations, we hope that a better understanding of welfare frontiers may contribute to an 'anthropology at home' in relation to Nordic Arctic resource projects. Inspired by the way that anthropology and political ecology on the global south have revealed unequal resource exploitation, we want to add a view to the less spectacular, but no less ubiquitous, resource projects, and to explore these as a soft kind of appropriation - of minorities, materials, peripheries, and subjects. As Halvard Vike (2015) has pointed out, bureaucratic settings are often more transparent and accessible to anthropologists in the Nordic countries than in other parts of the world. The relative ease with which Nordic scholars can move across hierarchies and organizational boundaries enables anthropology in Nordic countries to analyse the relations between everyday lives and institutional contexts, thus exploring welfare governance as it unfolds in everyday practices. Arguably, when it comes to resource uses and policies in the Nordic countries, the relative transparency of bureaucratic practices (often accompanied by rather widespread trust in state mechanisms) also spurs a kind of obligation: if resources are (ideally) equally distributed on the basis of sound and transparent governance, so is the responsibility to craft sustainable futures and liveable lands with replenished refuges (cf. Haraway 2015). The welfare frontiers of 'first world' anthropogenic landscapes demand our attention, and we need to bring resource projects home.

\section{Generating Natural Resources in a Nordic Arctic Anthropocene}

Overall, our aim with this thematic section is to make three anthropological interventions. First, we want to show that to make Nordic Arctic landscapes resourceful relies on ideas about optimal utilization, a sense of shared ownership, and ideals of redistribution, as much as on inherent landscape features or qualities. Secondly, we wish to contribute to an anthropology of northern Europe as seen through resource frontiers. The notion of resource frontiers is often explored in ethnographic studies of non-western and global south contexts 
(see e.g. Cons and Eilenberg 2019). By contrast, we explore natural resource development as linked to specific welfare state projects, even if these sometimes build on national and colonial centre-periphery dynamics of their own. Seeing Nordic welfare projects through such a focus on resource landscapes (and vice versa), leads us to our third intervention: We want to offer an understanding of resource development in the Nordic Arctic as yet another instantiation of anthropogenic environmental disturbance, through what we tentatively specify as a 'Nordic Arctic Anthropocene'. This implies looking carefully into local first world versions of resource use, where the binaries between exploiter and exploited, beneficiary and victim, or colonizer and colonized, may not be obvious.

In a recent article, Gabrielle Hecht (2018) tells a disturbing story of the life and closing down of a uranium mine in Gabon, West Africa. Part of her important message is to suggest the notion of an African Anthropocene: 'Thinking with an African Anthropocene reminds us of who pays the price for humanity's planetary footprints, so as to better grasp the kinds of entanglements - and futures - people face in our treacherous times' (2018:135). Our ambition is in line with hers, but our cases point to a much muddier picture of heroes and culprits. For better or for worse, our cases take us beyond blame as residing clearly with some and to a more all-inclusive responsibility. This distributed responsibility is one effect of the egalitarian welfare frontier practices. The important point here is that we do not take the Nordic Arctic resource landscapes that we explore as metaphors for the rest of the world. Indeed, in line with Bubandt and Tsing (2018), the very specificity of the welfare frontiers featured here is the point, as it allows us 'to take advantage of the irregularity of global spaces to understand the entanglement of human and nonhuman histories' (Bubandt and Tsing 2018: 6). Put differently, this special section locates resource landscapes in benign North European welfare projects and uses this location to qualify and specify environmental practices in the Anthropocene.

In so doing, we want to contribute to ongoing anthropological work towards grounding the current problems of ecological degradation even if in some of our cases this degradation is of a non-spectacular kind. In a recent roundtable discussion, Anna Tsing and Bruno Latour (Latour et al. 2018) identify one of the roots of the current global environmental crisis as the practice of de-territorializing or 'de-soiling' resources and land. The current crisis of ecological degradation is for a large part rooted in capitalist accumulation by dispossession, which in turn is nurtured by a modern fantasy of treating and 
exploiting natural resources as if they were not localized in specific places. What we do here is to analyse some of the processes of dispossession - and 'repossession' - through specifying how the making of Nordic Arctic resources is accomplished historically and practically. Unpacking these processes opens up avenues for considering how these landscapes could be inhabited and governed differently, and for articulating a more grounded anthropological critique.

\section{Acknowledgements}

This thematic section is a result of collaborative research in Copenhagen and Oslo. Our two related research projects cross-fertilized each other, and we are very grateful to The Danish Council for Independent Research's Sapere Aude programme for funding the project Natural Goods? Processing Raw Materials in Global Times, and to the Oslo Centre for Advanced Studies (CAS) for hosting the project Arctic Domestication in the Era of the Anthropocene (2015-16). Thanks to participants and collaborators.

Frida Hastrup is associate professor in ethnology at the Saxo Institute, University of Copenhagen. E-mail: hastrup@hum.ku.dk

Marianne Elisabeth Lien is professor at the Department of Social Anthropology, University of Oslo. E-mail: m.e.lien@sai.uio.no

\section{References}

Anderson, D. and M. Nuttall (2004), Cultivating Arctic Landscapes. Knowing and Managing Animals in the Circumpolar North (Oxford: Berghahn).

Bravo, M. and S. Sörlin (eds) (2002), Narrating the Arctic. A Cultural History of Nordic Scientific Practices (Canton, MA: Science History Publications).

Brichet, N. (2018), 'Timely Rubies: Temporality and Greenlandic Gems', The Extractive Industries and Society 5, no. 2: 267-273.

Brichet, N. and F. Hastrup (2018), 'Industrious Landscaping: The Making and Managing of Natural Resources at Søby Brown Coal Beds', Journal of Ethnobiology 38, no. 1: 8-23.

Bruun, M.H., G.S. Jakobsen and S. Krøijer (2011), 'Introduction. The Concern for Sociality - Practicing Equality and Hierarchy in Denmark', Social Analysis 55, no. 2: 1-19. 
Bubandt, N. and A. Tsing (2018), 'Feral Dynamics of Post-industrial Ruin: An Introduction', Journal of Ethnobiology 38, no. 1: 1-7.

Cons, J. and M. Eilenberg (2019), Frontier Assemblages: The Emergent Politics of Resource Frontiers in Asia (New York: Wiley Publishers).

Crosby, A. W. [2004] (2015), Ecological Imperialism: The Imperial Expansion of Europe. 900-1900. 2nd ed. (Cambridge: Cambridge University Press).

Crutzen, P. J. and Stoermer, E. F. (2000), 'The "Anthropocene"'. Global Change Neresletter 41: 17-18.

Flora, J. (2019), Wandering Spirits. Loneliness and Longing in Greenland (Chicago: Chicago University Press).

Gan, E. A. Tsing, H. Swanson and N. Bubandt (2017), 'Introduction: Haunted Landscapes of the Anthropocene', in A.L. Tsing, N. Bubandt, E. Gan and H.A. Swanson (eds) Arts of Living on a Damaged Planet (Minneapolis: University of Minnesota Press).

Grove, J. V. (2019), Savage Ecology. War and Geopolitics at the End of the World (Durham, NC: Duke University Press).

Gullestad, M. (1992), The Art of Social Relations: Essays on Culture, Social Action and Everyday Life in Modern Norway (Oslo: Scandinavian University Press).

Haraway, D. (2015), 'Anthropocene, Capitalocene, Plantationocene, Chthulucene: Making Kin', Environmental Humanities 6, no. 1: 159-165.

Hastrup, F. (2014), 'Mod nye frugtmarkeder. Forarbejdning af naturressourcer i kulturanalyse' Tidsskriftet Kulturstudier 5, no. 2: 8-23.

Hastrup, F. (2018), 'Natural Goods on the Fruit Frontier: Cultivating Apples in Norway', in H. Swanson, M. Lien and G. Ween (eds), Domestication Gone Wild: Politics and Practices of Multispecies Relations (Durham, NC: Duke University Press).

Hastrup, K. (2010), Vinterens hjerte. Knud Rasmussen og hans tid (Copenhagen: Gads Forlag)

Hastrup, K. (2015), Thule på tidens rand (Copenhagen: Lindhardt og Ringhoff).

Hecht, G. (2018), 'Interscalar Vehicles for an African Anthropocene: On Waste, Temporality, and Violence', Cultural Anthropology 33, no. 1: 109-141

Hylland Eriksen, T. and E. Schober (2018), 'Economies of Growth or Ecologies of Survival?', Ethnos 83, no. 3: 415-422.

Høst, J. (2016), 'Changing Rural Paradigms. Rural Ethnology between State Interest and Local Activism', Ethnologia Scandinavica 46: 124-141.

Keskinen, S. et al. (eds) (2016), Complying with Colonialism: Gender, Race and Ethnicity in the Nordic Region (London: Routledge).

Kristoffersen B. and Langhelle O. (2017), 'Sustainable Development as a GlobalArctic Matter: Imaginaries and Controversies', in K. Stephen and S. Knecht (eds), Governing Arctic Change. (Palgrave Macmillan, London).

Latour, B., I. Stengers, A. Tsing and N. Bubandt (2018), 'Anthropologists Are Talking - About Capitalism, Ecology, and Apocalypse', Ethnos 83, no. 3: 587-606.

Lien, M. E. (2014), 'Fluid Subsistences: Towards a Better Understanding of Northern Livelihoods', Polar Record 50, no. 4: 440-441.

Lien, M. E. (2015), Becoming Salmon; Aquaculture and the Domestication of a Fish (Oakland, CA: University California Press).

Lien, M. E. (2017), 'Unruly Appetites. Salmon Domestication all the way Down', in A. Tsing et al. (eds), Arts of Living on a Damaged Planet (Minneapolis, MN: University of Minnesota Press), 107-24. 
Lien, M. E. (2018), 'Ducks into Houses', in H. A. Swanson, M. E. Lien and G. B. Ween (eds), Domestication Gone Wild: Politics and Practices of Multispecies Relations (Durham, NC: Duke University Press).

Livingston, J. (2019), Self-Devouring Growth. A Planetary Parable as Told from Southern Africa, (Durham and London: Duke University Press).

Moore, J. W. (2014), 'The End of Cheap Nature, or: How I learned to Stop Worrying about 'the' Environment and Love the Crisis of Capitalism', in C. Suter and C. Chase-Dunn (eds), Structures of the World Political Economy and the Future of Global Conflict and Cooperation (Berlin: LIT), 285-314.

Naum, M. and J. Nordin (eds.) (2013), Scandinavian Colonialism and the Rise of Modernity (New York: Springer).

Norges Bank (2020), Norges Bank Investment Management: The Fund. www.nbim. no/ (accessed 20 January 2020).

Nuttall, M. (2012) 'Imagining and Governing the Greenlandic Resource Frontier'. Polar Journal 2, no.1: 113-24.

Regeringen (2018), Bedre Balance II: www.regeringen.dk/nyheder/udflytning-afstatslige-arbejdspladser-ii/ (accessed 30 August 2019).

Richardson, T. and G. Weszkalnys (2014), 'Introduction: Resource Materialities'. Anthropological Quarterly 87, no. 1: 5-30.

Rosing, M. and R. Knudsen (2014), Til gavn for Grønland, Udvalget for Samfundsgavnlig Udnyttelse af Grønlands Naturressourcer. Published by Ilisimatusarfik \& University of Copenhagen: https://greenlandperspective.ku.dk/this_is_greenland_ perspective/background/report-papers/Til_gavn_for_Gr_nland.pdf.

Scott, J. (1999), Seeing Like a State (New Haven, CN: Yale University Press).

Swanson, H., N. Bubandt and A. Tsing (2015), 'Less Than One but More Than Many. Anthropocene as Science Fiction and Scholarship-in-the-Making', Environment and Society: Advances in Research no. 6: 149-166.

Tsing, A. L. (2005) Friction. An Ethnography of Global Connection (Princeton: Princeton University Press).

Tsing, A.L. (2015), The Mushroom at the End of the World. On the Possibility of Life in Capitalist Ruins (Princeton, NJ: Princeton University Press).

Vike, H. (2015), 'Antropologien og den skandinaviske velferdsstaten', Tidsskriftet Antropologi, 72: 5-10.

Vuorela, U. (2016), 'Colonial Complicity; The "Postcolonial" in a Nordic Context', in S. Keskinen et al. (eds), Complying with Colonialism: Gender, Race and Ethnicity in the Nordic Region (London: Routledge).

Ween, G. B. (2015), 'Kevo subarktisk forskningsstasjon: villmark, arkitektur og kjønn i et vitenskapelig hjem i finsk Lappland', Tidsskrift for Kjønnsforskning 39, no. 2: 130-149.

Whyte, K. (2018), 'Settler Colonialism, Ecology and Environmental Injustice'. Environment and Society 9: 125-144. 